\title{
Cetacean sightings, mixed-species assemblages and the easternmost record of Indopacetus pacificus from the northern Indian ocean
}

\author{
Anoukchika D. llangakoon ${ }^{1 *}$ and Abigail K. Alling ${ }^{2}$
}

\begin{abstract}
A visual survey of cetaceans was carried out during a voyage from Singapore to Sri Lanka, through the Straits of Malacca, Andaman Sea and across the Bay of Bengal in the northern Indian Ocean in November/December 2012. Forty sightings of 11 cetacean species were recorded in 19 days of observation. Two mixed-species associations of interest were recorded. One of these contained four species of odontocetes in association with each other. The second group was of Indopacetus pacificus in association with Globicephala macrorhynchus and this while being the easternmost live sighting of I. pacificus in the northern Indian Ocean is also the first such mixed group in the Bay of Bengal.
\end{abstract}

Keywords: Bay of Bengal, Northern Indian Ocean, Cetaceans, Mixed-species assemblages, Indopacetus pacificus

\section{Introduction}

There have been few offshore cetacean surveys in Asia and there is a particular dearth of knowledge from the Bay of Bengal area of the northern Indian Ocean. While some countries around the rim of the Indian Ocean have carried out surveys in coastal waters, dedicated offshore cetacean surveys have rarely been undertaken in this area. Therefore, almost all of the knowledge about marine mammal diversity and distribution has come from observations in coastal waters (Alling, 1986; Anderson, 2005; Broker \& Ilangakoon,2008; Ilangakoon, 2008; Smith et al., 2008; Smith \& Tun, 2008; Ilangakoon, 2009; Ilangakoon \& Perera, 2009; Minton et al., 2010; Mansur et al., 2011; Clark et al., 2012; de Vos et al., 2012) and records of dead and stranded animals (Leatherwood \& Reeves 1989; Chantrapornsyl et al., 1996; Ilangakoon, 2006, Ilangakoon, 2012a). While dedicated cetacean surveys have been sparse throughout the northern Indian Ocean region (Ballance and Pitman 1998; De Boer, 2000) the only offshore records in the Bay of Bengal have

\footnotetext{
*Correspondence: ai.flukes@gmail.com

'Member, Cetacean Specialist Group of IUCN, 215, Grandburg Place,

Maharagama, Sri Lanka

Full list of author information is available at the end of the article
}

come from observations using platforms of opportunity (Leatherwood et al., 1984; Afsal et al., 2008).

Between 20 November and 12 December 2012, a visual survey for cetaceans was carried out onboard sailing vessel Mir while transiting from Singapore to Sri Lanka. The journey began in the Straits of Malacca and continued across the Andaman Sea and Bay of Bengal to Galle, Sri Lanka (Fig. 1). The route was chosen specifically to cross through the Ten Degree Channel $\left(10^{\circ} \mathrm{N}\right.$ Latitude) instead of the more direct route through the Great Channel $\left(6^{\circ} \mathrm{N}\right.$ Latitude). It is an unusually deep passage that has strong tides and currents coursing through several $1000 \mathrm{~m}$ depth contours running parallel to each other through the channel. Previously no cetacean surveys with published results have taken place in this passage area.

\section{Materials and methods}

The vessel Mir, a 113' two-masted ketch with a cruising speed of 3-6 knots was used as the dedicated platform for this survey. One primary observer, stationed on the bow scanning $180^{\circ}$ ahead kept a constant watch during daylight hours. The primary observer was assisted by the helmsman who was positioned just off-centre on the port side of the vessel aft of mid-ship. All sightings were 


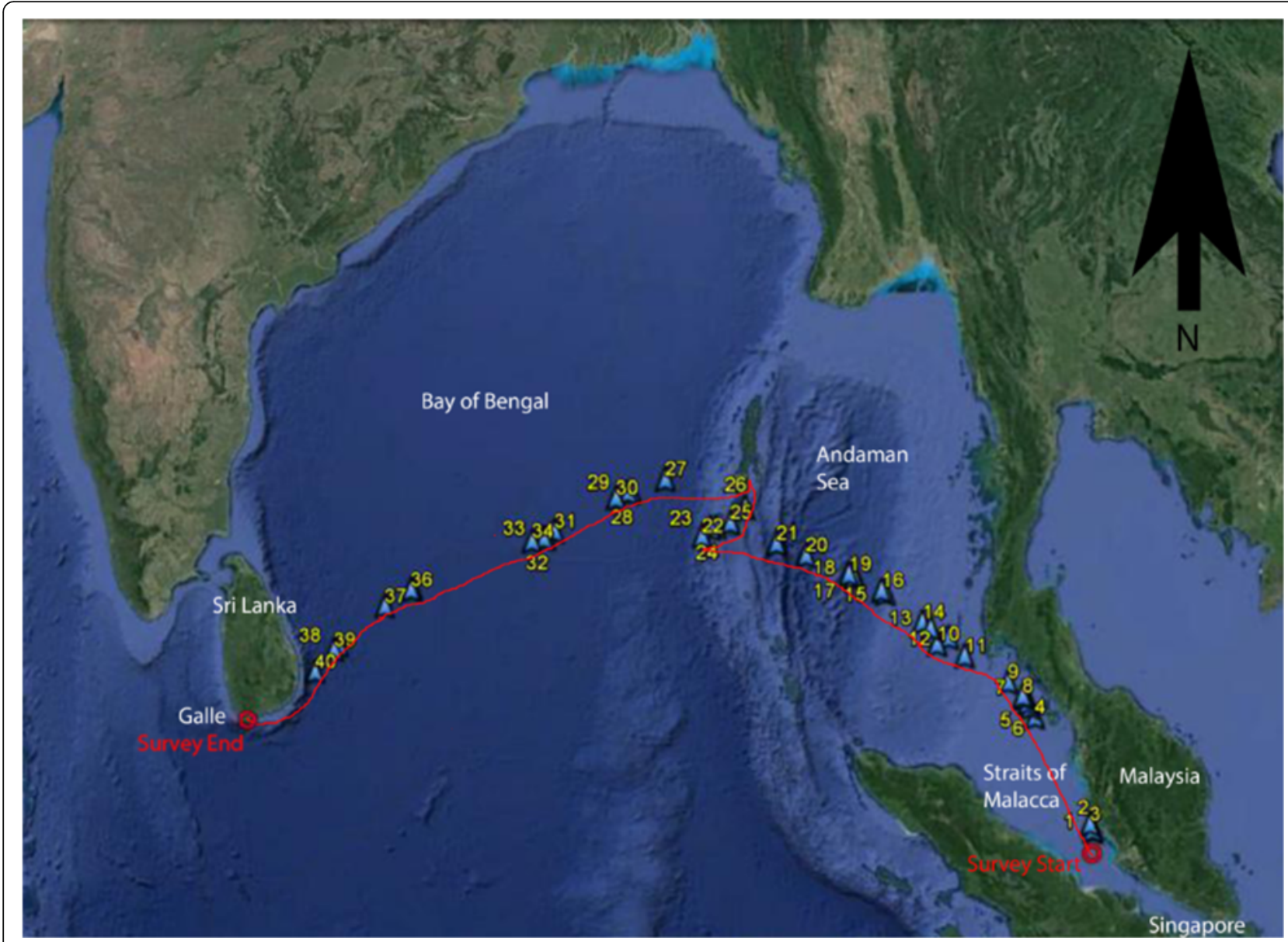

Fig. 1 Survey track and cetacean sighting locations

recorded in passing mode while the vessel maintained its preplanned course and no attempts were made to approach any of the cetaceans sighted.

For each sighting, the date, time, GPS location, species, number of individuals, behaviour and other pertinent information such as group composition, associated organisms and sea state were recorded. Animals were photographed opportunistically to aid identification but as all observations were in passing mode this was possible only when animals approached the vessel. Here we report all cetaceans sighted over the 19 days of observation and discuss some of the significant sightings including mixedspecies groups, in terms of expanding knowledge on the cetaceans in the northern Indian Ocean and particularly in the offshore areas of the Bay of Bengal.

\section{Results}

The survey commenced at 0800 on 22 November in the Straits of Malacca $\left(3^{\circ} 7^{\prime} 30^{\prime \prime} \mathrm{N} ; 100^{\circ} 41^{\prime} 33^{\prime \prime} \mathrm{E}\right)$ once Mir was outside of the main shipping lane and was completed when reaching the approach to Galle Harbour in Sri
Lanka $\left(5^{\circ} 53^{\prime} 48^{\prime \prime} \mathrm{N} ; 80^{\circ} 29^{\prime} 6^{\prime \prime} \mathrm{E}\right)$ at 0800 on 12 December 2012 (Fig. 1). An estimated distance of $1,660 \mathrm{~nm}$ was travelled, with good sighting conditions on all survey days except on 30 November when squalls and an opposing easterly current greater than 4 knots was prevalent just west of the Ten Degree Channel and the Andaman Islands.

Forty cetacean sightings were recorded over the survey period and all sightings were of odontocetes. Species were positively identified in 36 of the 40 sightings due to good sighting conditions and experienced observers while four sightings were recorded as unidentified species. A total of 11 species were positively identified including long-snouted spinner dolphin (Stenella longirostris Gray, 1828), pantropical spotted dolphin (Stenella attenuata Gray, 1846), striped dolphin (Stenella coeruleoalba Meyen, 1833), common bottlenose dolphin (Tursiops truncatus Montagu,1821), Indopacific bottlenose dolphin (Tursiops aduncus Ehrenberg, 1833), common dolphin (Delphinus capensis Gray, 1828), Irrawaddy dolphin (Orcaella brevirostris 
Gray, 1866), rough-toothed dolphin (Steno bredanensis Lesson,1828), short-finned pilot whale (Globicephala macrorhynchus Gray, 1846), Longman's beaked whale (Indopacetus pacificus Longman, 1926) and sperm whale (Physeter macrocephalus Linnaeus, 1758) (Table 1).

Stenella longirostris was the most frequently observed species encountered in 21 of the 40 sightings (Table 1). The only large whale sighting, of $P$. macrocephalus was in deep water $(>1000 \mathrm{~m})$ in the Ten Degree Channel off the Andaman Islands. Two mixed-species assemblages were recorded among the sightings and both occurred in the Bay of Bengal. The first of these occurred at location $11^{\circ} 21^{\prime} 83^{\prime \prime} \mathrm{N} ; 90^{\circ} 55^{\prime} 14^{\prime \prime} \mathrm{E}$ at 1414 on 5 December 2012 and this group of over 100 animals included four species: S. longirostris, S. coeruleoalba, S. attenuata and T. truncatus. This entire group was moving fast in a southerly direction and flying fish (Hirundichthys spp.) were also observed leaping among the dolphins. The second mixed-species assemblage occurred at location $09^{\circ} 59^{\prime} 57^{\prime \prime} \mathrm{N} ; 88^{\circ} 01^{\prime} 18^{\prime \prime} \mathrm{E}$ at 0825 on 7 December 2012 and comprised of the two species I. pacificus and G. macrorhynchus in a small group totalling 9-12 animals. When first sighted, three animals of the species $I$. pacificus appeared to be surfacing after a deep dive as they surfaced at a steep angle, with visible blows, which aided species identification along with their bulbous melon, large size and falcate pointed dorsal fin (Dalebout et al., 2003). They were soon followed by 6-9 G. macrorhynchus that surfaced beside them, after which they all swam away steadily in a southeasterly direction as one group. Although this group was photographed the animals were moving away, against the light, resulting in low quality photographs, not fit for publication.

Table 1 Cetacean sightings by species and location number as shown in Fig. 1

\begin{tabular}{lll}
\hline Species & $\begin{array}{l}\text { No. of } \\
\text { sightings }\end{array}$ & Sighting numbers as in Fig. 1 \\
\hline Stenella longirostris & 21 & $\begin{array}{l}3,4,5,6,8,9,11,12,13,14,16,19, \\
25,26,27,30,32,34,35,38,39,40\end{array}$ \\
Stenella coeruleoalba & 2 & 27,37 \\
Stenella attenuata & 3 & $27,31,37$ \\
Tursiops aduncus & 6 & $1,7,18,22,23,24$ \\
Tursiops truncatus & 2 & 27,29 \\
Steno bredanensis & 1 & 17 \\
Orcaella brevirostris & 1 & 2 \\
Delphinus capensis & 1 & 36 \\
Globicephala & 1 & 33 \\
macrorhynchus & & 33 \\
Indopacetus pacificus & 1 & 21 \\
Physeter macrocephalus & 1 & $10,15,20,28$ \\
Unidentified delphinids & 4 &
\end{tabular}

\section{Discussion}

This is the first reported cetacean survey conducted across the Andaman Sea and Bay of Bengal, thus it is not possible to make a comparison with previous studies. While all 11 species recorded have been previously reported from northern Indian Ocean waters (Alling, 1986; Leatherwood and Reeves, 1989; Ballance and Pitman, 1998; Balance et al., 2001; Ilangakoon 2002, Anderson, 2005) some factors of interest that further our knowledge were noted during the sightings of the present survey and particularly so with the mixed-species groups.

Both mixed-species assemblages sighted during the present survey were of significance due to their composition and the species involved. The first was of interest due to four species being in association with each other in a single group. Mixed-species associations involving delphinids including Stenella species, Tursiops species and Globicephala species are not unusual and they have been reported from several areas of the worlds' oceans (Querouil et al., 2008; Rossi-Santos et al., 2009) including areas around the Maldive Islands and Sri Lanka in the tropical Indian Ocean (Ballance \& Pitman 1998; Anderson, 2005; Ilangakoon, 2012b). However, most such sightings contained two or three species at most while the present sighting included four species with three Stenella species and one Tursiops species. The most likely explanation for this association is foraging advantage as previously suggested for similar associations in the Azores and Sri Lanka (Querouil et al., 2008; Ilangakoon, 2012b). This is further substantiated by flying fish being observed with this group. However, it has also been suggested that predation risk can drive sympatric cetacean species to form temporary mixed-species aggregations (Kiszka et al., 2015). Since this sighting was in the deep open waters of the Bay of Bengal this is another possibility to be considered.

The second mixed-species group observed in the present survey is significant firstly as it contained I. pacificus, a species that is not commonly sighted anywhere and there is a relative paucity of information on this species in a worldwide context. Sighting records of $I$. pacificus in the northern Indian Ocean are mostly from the western Indian Ocean (Anderson et al., 2006) and this is only the second live sighting to be documented east of Sri Lanka. The only other reported sighting was southeast of Sri Lanka at location $06^{\circ} 18^{\prime} \mathrm{N} ; 85^{\circ} 50^{\prime} \mathrm{E}$ (Afsal et al., 2009) while the present sighting was in the central Bay of Bengal at location $09^{\circ} 59^{\prime} \mathrm{N} ; 88^{\circ} 01^{\prime} \mathrm{E}$. Therefore, this sighting was over $250 \mathrm{~nm}$ northeast of the sighting reported by Afsal et al. (2009), making it the easternmost sighting of this species recorded in the northern Indian Ocean to-date. Secondly, it has been reported that this species occasionally associates with $G$. macrorhynchus (Reeves et al., 2002) but only one such 
instance of association has been previously recorded in the northern Indian Ocean (Anderson, 2005) in the waters off the Maldive Islands. Therefore the present sighting is important in that it expands our knowledge on the range and behaviour of this little-studies species in the northern Indian Ocean.

The sighting of two P. macrocephalus near the Andaman Islands is also noteworthy as there are few recent records of this species from the area. The previously documented sightings of this species from this area are old records from American whaling log books prior to 1920 (Townsend, 1935) and opportunistic observations by British and Dutch merchant seamen (Brown, 1957; Morzer-Bruyns, 1971; de Silva, 1987), that mention sperm whales from the vicinity of the Andaman and Nicobar Islands. Although cetacean stranding and sighting records in Indian waters have been documented in the interim period (Sathasivam, 2004) no sperm whale sightings or strandings have been reported from the area around the Andaman Islands from the 1950's until the present sighting. It is not clear if this dearth of records is due to a lack of dedicated cetacean surveys in the area or because the species is rare in these waters. However, it is also worth mentioning that at the time this sighting was made a French-Indian seismic survey vessel was active in the area and seismic blasts were audible on the hydrophone deployed to attempt recording sperm whale clicks. The sighting was brief as the two whales fluked high and dived rapidly. This behaviour may have been an indication of disturbance due to the proximity of seismic blasts as has been observed elsewhere (Mate et al., 1994).

Of the eight sightings of Tursiops spp, observed during the survey, six were of $T$. aduncus in the shallow waters of the Andaman Sea while two were of T. truncatus in the deeper waters of the Bay of Bengal beyond the Andaman Islands. Although T. aduncus has been commonly reported in coastal waters of southeast Asian countries adjoining the Andaman Sea (Thailand, Myanmar) and in the Swatch of No-Ground off Bangladesh in the northern most regions of the Bay of Bengal, T. truncatus predominates around Sri Lanka on the western side of the Bay of Bengal. The present sightings were of interest however, because the clear demarcation of area of occurrence noted in this survey has not been documented before. This observation needs to be treated with caution due to the small number of sightings however, it is a point of interest for future surveys in this area to verify.

The present survey is only a starting point to fill the gaps in knowledge about cetacean occurrence and distribution in the offshore waters of the northeast Indian Ocean, particularly the Bay of Bengal. The data presented here indicates that a lot more work needs to be done in this area in order to gain a proper understanding of the importance of these waters as cetacean habitat and it is therefore suggested that more systematic surveys are undertaken in the future.

\section{Acknowledgements}

This study and voyage were made possible by support from The Ward Family Foundation, Kopcho Family Foundation and Swire Pacific Offshore. We wish to give special thanks to Captain Mark Van Thillo, and crew members Robert Thoren, Ed Baker, Ellie Heywood, Dinouk Perera and Leina Sato for their support in the research. We also thank the two reviewers for their comments.

\section{Authors' contributions}

$\mathrm{AA}$ and $\mathrm{Al}$ conceived the study and and participated in the on-board research. Al prepared the manuscript with input from AA. Both authors read and approved the final manuscript.

\section{Competing interests}

The authors declare that they have no competing interests.

\section{Author details}

${ }^{1}$ Member, Cetacean Specialist Group of IUCN, 215, Grandburg Place, Maharagama, Sri Lanka. ${ }^{2}$ Biosphere Foundation, P.O. Box 112636, Campbell, CA 95011-2636, USA.

Received: 8 September 2016 Accepted: 8 September 2016

Published online: 07 October 2016

\section{References}

Afsal W, Yousuf KSSM, Anoop B, Anoop AK, Kannan P, Rajagopalan M, Vivekanandan B. A note on cetacean distribution in the Indian EEZ and contiguous seas 2003-07. J Cetacean Res Manag. 2008;10(3):209-16.

Afsal W, Manojkumar PP, Yousuf KSSM, Anoop B, Vivekanandan B. The first sighting of Longman's beaked whale (Indopacetus pacificus) in the southern bay of Bengal. Mar Biodivers Rec. 2009;2:1-3.

Alling A. Records of odontocetes in the Northern Indian ocean (1981-1982) and off the coast of Sri Lanka (1982-1984). J Bombay Nat Hist Soc. 1986;83:376-94.

Anderson RC, Clark R, Madsen P, Johnson C, Kiszka J, Breysse O. Observations of Longman's beaked whale (Indopacetus pacificus) in the Western Indian ocean. Aquat Mamm. 2006;32(2):223-31.

Anderson RC. Observations of cetaceans in the Maldives, 1990-2002. J Cetacean Res Manag. 2005;7(2):119-35.

Ballance LT, Anderson RC, Pitman RL, Stafford K, Shaan A, Waheed Z, Brownell RL. Cetacean sightings around the Republic of the Maldives, April 1998. J Cetacean Res Manag. 2001;3(2):213-8.

Ballance LT, Pitman RL. Cetaceans of the western tropical Indian ocean: distribution, relative abundance, and comparisons with cetacean communities of two other tropical ecosystems. Mar Mammal Sci. 1998;14(3):429-59.

Broker KCA, llangakoon A. Occurrence and conservation needs of cetaceans in and around the Bar reef marine sanctuary, Sri Lanka. Oryx. 2008;42(2):286-91.

Brown SG. Whales observed in the Indian ocean. Notes on their distribution. Mar Observations. 1957;27(177):157-65.

Chantrapornsyl S, Adulyanukosol K, Kittiwathanawong K. Records of cetaceans in Thailand. Res Bull Phuket Biol Cent. 1996;61:39-63.

Clark RA, Johnson CM, Johnson G, Payne R, Kerr I, Anderson RC, Sattar SA, Godard CAJ, Madsen PT. Cetacean sightings and acoustic detections in the offshore waters of the Maldives during the northeast monsoon seasons of 2003 and 2004. J Cetacean Res Manag. 2012;12(2):227-34.

Dalebout ML, Ross GJB, Baker CS, Anderson RC, Best PB, Cockroft VG, Hinsz HL, Peddemors $V$, Pitman RL. Appearance, distribution and genetic distinctiveness of Longman's beaked whale, Indopacetus pacificus. Mar Mammal Sci. 2003;19(3): 421-61.

De Boer MN. A note on cetacean observations in the Indian ocean sanctuary and the South China sea, Mauritius to the Philippines, April 1999. J Cetacean Res Manag. 2000;2:197-200.

De Silva PHDH. Cetaceans (whales, dolphins and porpoises) recorded off Sri Lanka, India, from the Arabian Sea and gulf, gulf of Aden and from the Red Sea. J Bombay Nat Hist Soc. 1987:84(3):505-25.

De Vos A, Clark R, Johnson C, Johnson G, Kerr I, Payne R, Madsen P. Cetacean sightings and acoustic detections in the offshore waters of Sri Lanka: March-June 2003. J Cetacean Res Manag. 2012;12(2):185-93.

llangakoon AD. Whales and dolphins Sri Lanka. Colombo: WHT Publications; 2002. p. 99. 
Ilangakoon AD. Preliminary analysis of large whale strandings in Sri Lanka 1889-2004. Pak J Oceanography. 2006;2(2):61-8.

llangakoon AD. Cetacean species richness and relative abundance around the Bar reef marine sanctuary, Sri Lanka. J Bombay Nat Hist Soc. 2008;105(3):274-8.

Ilangakoon AD. Cetacean survey off southern Sri Lanka, 2008-2009 project completion report. UK: Whale and Dolphin Conservation Society; 2009. p. 25.

llangakoon, AD. A review of cetacean research and conservation in Sri Lanka. J Cetacean Res Manag. 2012a;12(2):177-83.

llangakoon AD. Cetacean diversity and mixed-species associations off Southern Sri Lanka. In Arai, N. (ed) Proceedings of the $7^{\text {th }}$ International Symposium on SEASTAR2000 and Asian Biologging Science, 8-9 March 2011. Bangkok, Thailand: Kyoto University Press; 2012b 68pp.

Ilangakoon AD, Perera LD. Cetacean and seabird survey off south-west Sri Lanka, 2008-2009. Hong Kong: Ocean Park Conservation Foundation; 2009. p. 37.

Kiszka JJ, Heithaus MR, Wirsing AJ. Behavioural drivers of the ecological roles and importance of marine mammals. Mar Ecol Prog Ser. 2015;523:267-81.

Leatherwood S, Peters R, Santerre R, Santerre M, Clarke JT. Observations of cetaceans in the northern Indian ocean sanctuary, November 1980 - May 1983. Rep Int Whaling Comm. 1984;34:509-20.

Leatherwood S, Reeves RR. Marine mammal research and conservation in Sri Lanka, Marine mammal technical report number 1. Nairobi: United Nations Environment Programme; 1989. p. 138.

Mansur RM, Strindberg S, Smith BD. Mark-resight abundance and survival estimation of indo-pacific bottlenose dolphins, Tursiops aduncus, in the swatch-of-no-ground, Bangladesh. Mar Mammal Sci. 2011;28(3):561-78.

Mate BR, Stafford KM, Lungblad DK. A change in sperm whale (Physeter macrocephalus) distribution correlated to seismic surveys in the Gulf of Mexico. J Acoustic Soc Am. 1994;965:33268-9.

Minton G, Collins T, Findlay K, Baldwin R. Cetacean distribution in the coastal waters of the sultanate of Oman. J Cetacean Res Manag. 2010;11(3):301-14.

Mörzer-Bruyns W.F.J. (1971) Field Guide of Whales and Dolphins. C. A. Meese, Amsterdam, Netherlands. 258pp.

Quérouil S, Silva MA, Cascăo I, Magalhăes S, Seabra MI, Machete MA, Santos RS. Why do dolphins form mixed-species associations in the Azores? Ethology. 2008;114:1183-94.

Reeves RR, Stewart BS, Clapham PJ, Powell JA. Guide to marine mammals of the world. New York: National Audubon Society, Alfred A. Knopf Inc; 2002. p. 527.

Rossi-Santos MR, Santos-Neto E, Baracho CG. Interspecific cetacean interactions during the breeding season of humpback whales (Megaptera noveaengliae) on the north coast of Bahia State, Brazil. J Mar Biol Assoc UK. 2009;89(5):961-6.

Sathasivam K. Marine mammals of India. Hyderabad: University Press (India) Private; 2004. p. 180.

Smith BD, Ahmed B, Mansur R, Strindberg S. Species occurrence and distributional ecology of nearshore cetaceans in the Bay of Bengal, Bangladesh, with abundance estimates for Irrawaddy dolphins Orcaella brevirostris and finless porpoises Neophocaena phocaenoides. J Cetacean Res Manag. 2008;10:45-58.

Smith BD, Tun MT. A note on the species occurrence, distributional ecology and fisheries interactions of cetaceans in the Mergui (Myeik) Archipelago, Myanmar. J Cetacean Res Manag. 2008;10:37-44.

Townsend $\mathrm{CH}$. The distribution of certain whales as shown by logbook records of American whaleships. Zoologica (NY). 1935;19(1-2), 1-50 +6 maps.

\section{Submit your next manuscript to BioMed Central and we will help you at every step:}

- We accept pre-submission inquiries

- Our selector tool helps you to find the most relevant journal

- We provide round the clock customer support

- Convenient online submission

- Thorough peer review

- Inclusion in PubMed and all major indexing services

- Maximum visibility for your research

Submit your manuscript at www.biomedcentral.com/submit

) Biomed Central 